\title{
Ghosts in the Machine: Narratives of Disappearance in French Fiction from the 1990s
}

\author{
Peter SCHULMAN \\ Old Dominion University \\ pschulma@odu.edu
}

Recibido: 08/12/2014

Aceptado: 08/05/2015

\begin{abstract}
This article examines narratives of disappearance in two French novels from the late 1990's, J.B. Pontalis's Un homme disparaît and Marie Darrieussecq's Naissance des fantômes, which are reflective of a general trend towards ghostliness in French fiction towards the end of the twentieth century. The article argues that these novels are emblematic of a fin de siècle malaise that Marc Augé termed surmodernité and that Paul Virilio has identified in terms of an era characterized by so much speed (as a result of an overabundance of technological innovations in communication such as email and faxes) that individuals have become less and less centered or inter-connected rather than the other way around. Pontalis and Darrieussecq's novels are particularly good examples of a certain need for some to "vanish" within hyper-developed, contemporary spaces. Through an exploration of Pontalis and Darrieussecq's characters' attempts at remembering their own personal narratives, the article will also examine the notion of fleeting "traces of memory" that linger within the unconscious of many despite constant barrages of memory-numbing stimuli.
\end{abstract}

Key words: J.B. Pontalis, Paul Virilio, Marc Augé, Marie Darrieussecq, surmodernité, disappearance, Un homme disparaît, Naissance des fantômes.

\section{Espectros en el aparato: el tema de la desaparición en la novela francesa en el periodo de los años 1990}

\section{Resumen}

Este artículo examina el tema de la desaparición en dos novelas francesas a finales de los años noventa, una novela de J.B. Pontalis y una otra de Marie Darrieussecq que son particularmente representativas de una tendencia fantomática en la novela francesa de finales del siglo. Nuestro texto propone que estas novelas representan un malestar general que Marc Augé llamó sobremodernidad y que Paul Virilio describe en términos de demasiada velocidad en nuestra época. Toda esta velocidad resulta en un gran aislamiento colectivo. Es la razón por la cual los personajes de Pontalis y Darrieussecq quieren desaparecer. Este escrito examina también la idea de "vestigios de la memoria" que existen en el inconsciente de muchas personas a pesar de demasiados estímulos urbanos.

Palabras clave: J.B. Pontalis, Marc Augé, Marie Darrieussecq, sobremodernidad, la desaparición, Un hombre desaparece, Nacimiento de los fantasmas. 


\title{
Le spectre dans la machine: notions de disparition dans le roman français des années quatre-vingt-dix
}

\begin{abstract}
Résumé
Cet article examinera le thème de la disparition dans deux romans français de la fin des années quatrevingt-dix, Un homme disparaît de J.B. Pontalis et Naissance des fantômes de Marie Darrieussecq, qui sont particulièrement emblématiques d'une tendance fantomatique dans le roman français vers la fin du vingtième siècle. Cet article proposera que ces romans représentent un malaise quasi fin de siècle que Marc Augé avait nommé surmodernité et que Paul Virilio avait identifié en termes d'une ère caractérisée par trop de vitesse (venant d'une surabondance d'innovations communicatives tel que les emails et les fax). Or toute cette vitesse aboutit à un isolement collectif plutôt qu'à un brassage. Les romans de Pontalis et de Darrieussecq représentent un besoin parmi certains de vouloir "disparaître" au sein d'espaces contemporains hyper-développés. Par le biais, d'une étude des personnages de Pontalis et de Darrieussecq, cet article examinera également la notion de "traces de mémoire" qui demeurent dans l'inconscient de beaucoup d'individus malgré le grand nombre de stimulants urbains.
\end{abstract}

Mots clés : J.B. Pontalis, Paul Virilio, Marc Augé, Marie Darrieussecq, surmodernité, disparition, Un homme disparaît, Naissance des fantômes.

Summary : The Culture of Speed. Pontalis's Vanishing Man. Darrieussecq's "Flying Dutchman” (Vaisseau Fantôme).

\section{Referencia normalizada}

Schulman, P. (2015). "Ghosts in the Machine: Narratives of Disappearance in French Fiction from the 1990s” Thélème. Revista Complutense de Estudios Franceses, Vol. 30, Núm. 2: 223-237. http://dx.doi.org/10.5209/rev_THEL.2015.v30.n2.47423

\section{The Culture of Speed}

"L’être ou le néant, voilà le problème”, Gabriel muses in Raymond Queneau's Zazie dans le métro. "Monter, descendre, aller, venir, tant fait l'homme qu'à la fin il disparaît” (1959 : 90). Could the same be said for contemporary French fictional characters as well? A quick survey of titles from our recent fin de siècle seem to corroborate Gabriel's assertion. From J-B Pontalis's Un homme disparaît (1996) to Marie Darrieussecq's Naissance des fantômes (1998), French fiction of the late 1990s seems to have been governed by a sense of ghostliness if not "evaporation" that begs the question of a recent Sophie Calle retrospective at the Centre Pompidou in Paris: "M'as-tu vue"? Indeed, as Paul Virilio has examined extensively in such books as L'Esthétique de la disparition and Bunker archéologie, modern life is so hyper-accelerated through technological gadgetry and soi-disant time-saving 
devices, that for many, a sense of community or solidarity has given way to isolation and melancholy. Rather than bringing people together, Virilio argues, the "picnoleptic"1 pace of modern society leads to an isolation-en-masse that reaches its zenith in an over-abundance of cyber-communities and email communication. It is a "conception assistée de l'existence: plaisir d'un rendez-vous à distance, d'une réunion sans réunion [...] perte d'intérêt pour notre prochain au profit d'êtres inconnus et lointains qui demeurent à l'écart, spectres sans importance qui n'encombrent pas notre emploi du temps" (Virilio, 1990: 48).

While the philosopher Gilles Lipovetsky had dubbed the 1980s "l'ère du vide," an empty era he thought was ruled by vanity and vapidity, Virilio considers the 1990's to be decidedly "l'ère du stress" as speed for speed's sake has taken over our daily lives. Using notions of transportation as a spring-board for his theory, Virilio observes that planes, trains and boats may well be able to go faster and faster, contemporary speed (as opposed perhaps to the nineteenth-century euphoria that speed opened up in terms of travel) actually engenders a creeping sense of inertia rather than of satisfaction through productivity: "L'ère du temps intensif n'est plus celle du moyen physique. Elle est, contrairement à celle du temps extensif de jadis, exclusivement celle du moyen de télécommunication, autrement dit: celle du surplace et de l'inertie domiciliaire" (Virilio, 1990 : 48). Moreover, using the Formula 1 racecar as a prototype for contemporary living, Virilio adds that the "Dragster" is particularly emblematic of the symptomatic rapidity that leads, in effect, to "nowhere in a hurry": "Comment aller nulle part, en tous cas, de moins en moins loin (400, 200m) mais de plus en plus vite?” (Virilio 1990: 48).

At the beginning of the 1990's, Marc Augé, with his theories of "surmodernite" had already put his finger on what he perceived as an acceleration of history brought about by a surplus of information, news and data:

À peine avons-nous le temps de vieillir un peu,” Augé notes, “que notre passé devient de l'histoire, que notre histoire individuelle appartient à l'histoire [...] Aujourd'hui, les années récentes, les sixties, les seventies, bientôt les eighties, retournent à l'histoire aussi vite qu'elles y étaient survenues. Nous avons l'histoire sur les talons. Elle nous suit come notre ombre, comme la mort” (Augé, 1992: 38).

Queneau's Gabriel may well have been prophetic in his vision of Parisian life as the contemporary is indeed no longer the post-modern but the over-modernized. If Pierre Nora could almost nostalgically try to preserve collective memory through

\footnotetext{
${ }^{1}$ MIT Press, in their publicity blurbs advertising Paul Virilo’s works, define Virilian "picnolepsy" in terms of: "The Aesthetics of Disappearance introduced his understanding of 'picnolepsy' - the epileptic state of consciousness produced by speed, or rather, the consciousness invented by the subject” (MIT Press Web Site, available at: https://mitpress.mit.edu/index:authors/Paul-Virilio [Latest access June 3, 2015]). Essentially a cinematic term for a rapid succession of images, Virilio coins his term to illustrate the exponential acceleration of contemporary daily life.
} 
the tender prisms of his "lieux de mémoires," Augé wistfully identifies the encroaching "non-lieux" that have usurped our quotidian: the anonymous and sterile spaces exemplified by malls, airports and bus stations. The homogenized and alienating aesthetic of the non-lieux have become indicative of a larger sense of alienation outside of and behind the walls of apartment buildings and houses where, presumably, a warm fireplace once heralded a cozy end to a tiring day. Augé sees the contemporary landscape in almost paradoxical terms:

Au moment même où l'unité de l'espace terrestre devient pensable et où se renforcent les grands réseaux multinationaux, s'amplifie la clameur des particuliarismes; de ceux qui veulent rester seuls chez eux ou de ceux qui veulent retrouver une patrie, comme si le conservatisme et le messianisme des autres étaient condamnés à parler le même langage: Celui de la terre et des racines (Augé, $1992: 48)$.

It is as though Augé were describing a mirror image of the Tower of Babel story in which, rather than diasporic difference, one standardized language of business and retail chains has replaced the warmer images of a quainter, quirkier time that Jacques Tati was able to delineate so clearly in his 1958 film Mon oncle. As Augé concludes, the parameters of modern life established by the proliferation of nonplaces forces new interpretations and analysis of the quotidian but with the same decentered gaze that $19^{\text {th }}$-century explorers discovered in "exotic" and faraway cultures: "Si l'expérience lointaine nous a appris à décentrer notre regard, il nous faut tirer profit de cette expérience. Le monde de la surmodernité n’est pas aux mesures exactes de celui dans lequel nous croyons vivre, car nous vivons dans un monde que nous n'avons pas encore appris à regarder” (Augé, 1992: 49). For Augé, there is only one solution to this over-acceleration of time and space: "Il nous faut réapprendre à penser l'espace” (Augé, 1992: 49).

How does one capture a space that disappears even before we can become aware of it? As Virilio understands it, the early days of photography, led by Daguerre and Niépce, ushered in an aesthetic of disappearance that replaced the ones based on appearance: "Where once the aesthetics of the appearance of an analogical, stable image of static nature predominated, we now have the aesthetics of the disappearance of a numerical, unstable image of a fleeting nature, whose persistence is exclusively retinal" (Virilio, 1999: 23). Yet, as Ackbar Abbas remarks, "there is something highly ambivalent about disappearance" (Abbas, 1997: 70). "A space of disappearance challenges historical representation in a special way, in that it is difficult to describe precisely because it can adapt so quickly that it becomes non-descript," Abbas continues. "We can think about a non-descript space as that strange thing: an ordinary, everyday space that has somehow lost some of its usual systems interconnectedness, a deregulated space. Such a space defeats description not because it is illegible and none of the categories fit, but because it is hyperlegible and all the categories fit” (Abbas, 1997: 73). For Abbas, it is no longer a question of uncanny "déjà-vu", necessarily, that characterizes the aesthetic sensibility of our era, but rather a "déjà-disparu”. Quoting Henri Lefebvre’s comments on what he considers "the abstract space of neo-capitalism" (Abbas, 
1997: 48), he writes: "That which is merely seen (and merely visible) is hard to see" (Abbas, 1997: 48).

Just as one learns to read a Bonnard painting, for example, by not concentrating on the center of the canvas, which is left empty of figures or objects, like a wideangle camera lens, but by focusing on the margins where the forms and objects have seemingly dissolved, so must one read certain "fantôme"-like French works that put into motion the "déjà-disparu" Abbas uses to describe modern Hong Kong. If Bonnard and the Nabis (or "prophets" in Hebrew) movement he belonged to painted not from life, but from memory, so do such writers as J.-B. Pontalis and Marie Darrieussecq who capture what Abbas describes in terms of a space in which

the visual is both ineluctable and elusive at the same time. Disappearance is certainly the result of speed, understood both as the speed of historical changes and as the technological speed of information and communication. But it is also the (negative) experience of an invisible order of things, always teetering just on the brink of consciousness (Abbas, 1997: 48).

Both Pontalis and Darrieussecq are trained psychoanalysts and have written much on notions of absence and oblivion. Pontalis, for example, as Edmundo Gomez Mango understands him,

never ceased to inhabit and explore that space of the intermediate, going through other forms of 'between' and 'in-between,' terms that often recurred under his pen [...]He often dwelled inbetween psychoanalysis and literature or, in the space of art, between the hallucinatory fulfillment of the life of desire and real life (Mango, 2014 : 525).

Similarly, many of Darrieussecq's novels treat or refer to ghosts and disappearances: Naissance de fantômes (1998); Bref séjour chez les vivants (2001) and later, Tom est mort (2007). As Darrieussecq admits, her involvement in psychoanalysis gave her the tools to see her fictional characters and the world they inhabit with more clarity: "Freud, j'ai lu un peu et pratiqué beaucoup, c'est-à-dire que j'ai fait une analyse, huit ans, qui m’a permis entre autres de séparer [...] ma névrose de mon écriture [...] je suis maintenant devenue psychanalyste. [...] Avant mon analyse j'ai beaucoup lu ses récits de cas comme des polars. Et après mon analyse...aussi” (Darrieussecq, 2006: en ligne). Indeed, Pontalis and Darrieussecq, through their work, write as though they were "psychoanalytic detectives" uncovering the symptoms that led French society towards an "esthetic of disappearance" and oblivion. Michel de Certeau, as early as the 1970's, had already noticed that "on n’habite que les lieux hantés" (de Certeau, 1990: 196), but by whom? By what? These are the questions these writers bring to mind.

\section{Pontalis's Vanishing Man}

While J-.B Pontalis is well known for his scientific work on psychoanalysis, his novels have also caught the eye of the reading public. Among them, Un homme disparaît, is surely the most intriguing. Used to seeing a certain stranger at the Café de l'Oubli, the narrator of Un homme disparaît suddenly develops an urge to 
connect with him on a deeper level. He becomes an object of his fascination: “Bizarrement, j'ai l'idée que cet homme attend de moi quelque chose qu'il attend non que je le questionne mais que je lui parle. Et moi, attendrais-je quelque chose de lui? Qui est-il? D’où vient-il?” (Pontalis, 1996: 14). He begins to speculate on who he might be, imagining that he is first walking towards his own death: "Parfois, je me dis que cet homme marche vers la mort et qu'il le sait [...]. Il paraît vigoureux mais il sait que ses pas mènent vers la mort, il sait qu'il va mourir” (Pontalis, 1996: 14). At another point he even thinks he might already be a ghost haunting the café: "non de s'assurer qu'il n'a pas été oublié mais de voir si on le reconnaît, si je, peutêtre, le reconnais" (Pontalis, 1996 :14). One day, feeling the urge to finally speak to him, he chases after him as he boards a bus only to lose him as the doors close. The stranger dissolves among the other passengers: "Il disparaît parmi les passagers avec un singulier sourire, comme s'il voulait. Lui dont je jurerais qu'il ne possède rien, se faire du premier venu un ami avant de le quitter" (Pontalis, 1996 :15). As the bus leaves, the narrator scolds himself for not having pursued him as he is seized by an overwhelming and unexpected emptiness: "Soudain la ville n'est plus comme lui qu'un fantôme” (Pontalis, 1996: 15).

Soon after the stranger vanishes, the narrator himself feels as though he has become a ghost as his apartment becomes empty (his wife and kids go on vacation) and he floats from one vacant room to the next: "Je me sens pas chez moi, j'erre d'une pièce à l'autre. La télévision ne fonctionne pas” (Pontalis, 1996: 15). Later, he haunts the spots he used to see the stranger in and feels compelled to write his story, or rather a composite of a story involving "un homme qui, lui, porterait un nom d'un homme que j'avais réellement connu avant que, lui aussi, ne devienne un fantôme" (Pontalis, 1996: 17). As in Queneau's Le Chiendent when a shadow is brought to life as a character when it starts thinking (and activates Descartes' maxim, "Je pense donc je suis"), the fictional stranger becomes truly real because the narrator begins thinking of his past, in conjunction with his own past, as well as a friend's past: “Je dois l'inventer. Je dois le rêver [...] Oui, c'est cela, le recomposer avec des restes” (Pontalis, 1996: 19). The stranger becomes another, a certain Julien Beaune, who, in turn, becomes "celui que je vois dans mon miroir quand le commencement du jour se confond avec sa fin" (Pontalis, 1996: 19). The shadow takes shape, "Je veux donner les contours à une ombre portée," (Pontalis, 1996: 19) in order to be used as a weapon against the vortex of forgetfulness the narrator might have fallen through if the stranger had not stimulated such an exercise in remembrance.

The narrator will follow Beaune through his childhood and adolescence through young adulthood during the Occupation in Paris, as German soldiers his own age patrol the métro and Jewish classmates of his begin disappearing. Beaune will attempt to confront the collective guilt that begins to set in, "Il pense à tout ce sur quoi les hommes font silence. Il pense qu'il n'y a que l'homme pour être criminel” (Pontalis, 1996: 78). After the war, he volunteers at the Hotel Lutétia to help Jewish refugees resettle after the Holocaust and remembers a vicious classmate who turned Jews in calmly and who said sinisterly: "Ne t'inquiète pas. Je ne t'ai pas 
oublié” (Pontalis, 1996: 79). Later, Beaune becomes a doctor, then, in fact, the narrator's doctor. In post-war France, he meets Jewish patients and his haunted by their presence: “[Il] rédige l'ordonnance mais il est tout occupé à se déprendre de l'idée que son visiteur est un revenant” (Pontalis, 1996: 96). As he becomes successful, he attends international medical conferences with such themes as "Approches Socio-Culturelles et Médico-Psychologiques de l'oubli” (Pontalis, 1996 : 97). Towards the end of the novel, the narrator and Beaune even go to the Café de l'Oubli together as their parallel universes merge at the café counter where they learn brief snippets about each other: "Les mots que nous échangeons sont maigres, nos rencontres brèves et pourtant, plus le temps passe; plus je m'attends à cet homme [...] Il nous faut nous présenter sous un masque” (Pontalis, 1996: 123). Indeed, Pontalis plays with notions of mirrors, masks and shadows throughout the novel in order not only to chronicle the instances of disappearance of the mysterious stranger, or even dopplegänger who inspires the narrator to write down his thoughts, but also to bring attention to the collective memory that haunts France, as well as the narrator, in a style that is reminiscent of many of Patrick Modiano's novels such as La place de l'étoile or the many novels that he had written in the 1990s with the theme of disappearance such as Chien de printemps or Dora Bruder.

If, in the middle of the novel, during the war, Beaune has trouble looking at himself in the mirror because he has become so morose, Pontalis seems to be alluding to the culture of silence, the willing suppression of memory that would characterize the French post-war psyche:

Le matin, quand il se force à sortir de son lit, il n'a pas besoin de se voir dans la glace au dessus du lavabo pour savoir que son regard est vide, absent. Et, quand il se trouve face au miroir, ce n'est pas pour examiner son visage mais pour s'assurer qu'il y a bien quelqu'un là. Quelqu'un qui aurait une forme (Pontalis, 1996: 123).

It is a collective and individual trauma the narrator is alluding to through Beaune: "Il faudrait rompre avec les mots, les phrases, les gestes. Cesser de se fier aux émotions qui s'effacent” (Pontalis, 1996: 123). As such, when the narrator and Beaune speak to each other for the first time, man to man, face to face, it is with great discretion and carefulness: “C'est toujours de façon indirecte que je peux l'approcher" (Pontalis, 1996: 123). When the narrator loses a beloved house he used to rent regularly over the summer in Brittany, his conversations with Beaune trigger a flood of his own memories that act as a cushion for the sadness he feels at losing his summer haven: he realizes that his intense memory of place has in fact replaced his memories of people both in intensity and in fondness, much to the chagrin of his wife:

C'est que la mémoire des lieux n'est devenue plus assurée que celle des personnes que j'ai pu connaître," he admits, "Elle est le remède que j’ai trouvé au morcellement des jours aussi bien qu'à leur répétition. Avec elle, le temps trouve un ordre qui est le mien. Cette mémoire-là est le fond du tableau sur quoi je peux dessiner les visages, elle est la musique sur quoi se détachent les voix singulières (Pontalis, 1996: 127). 
In his psychoanalytic treatise Ce temps qui ne passe pas, Pontalis compares the notion of remembrances in terms of "screens" to "traces" of memory that are both hidden and maintained at the same time. Augé understands Pontalis's "mnestic traces" in terms of "traces [that] are apparently trivial and arise unexpectedly in the mind of those who let themselves drift off in reverie or make the effort of selfanalysis [...] In some way these traces are disconnected from any possible or credible tale; they have been freed from the remembrance" (Augé, 2004: 23) and as Pontalis explains himself, that which is most apparent "is not the remembrance but the traces, the signs of absence" (Augé, 2004: 23). For Pontalis, memories in and of themselves are not as accurate or as interesting as free associations which, in a Surrealist manner "separate the established, well-rooted links in order to have other ones appear that are often dangerous liaisons" (Augé, 2004: 23). In this manner, the stranger at the beginning of the novel is the "trace" that triggers the narrator towards an examination of his own memories as well as a type of mnemonic ricochet from Beaune (upon whom the narrator's inner worries and anxieties are projected). When Beaune, like the stranger, disappears from the Café de l'Oubli, the narrator is unable to ever find him again. His old coordinates and office have been usurped by another doctor and, as in the film (which the narrator enjoys) The Lady Vanishes, the narrator knows that Beaune is out there somewhere, doing good work: "Je ne l'imagine pas mais, je sais que Julien Beaune n'a fait que disparaître, vanishes. Il s’absente. Il est là" (Pontalis, 1996: 133). He writes that he has done nothing but vanish as if to say that it is not an act that one need worry about because, in the narrator's world, he is more present in his absence than he is when he is actually with the narrator in person.

At the very end of the novel, yet another passerby catches the narrator's eye at the café, a man the café owner calls "le cinglé" because he rants hysterically, and incessantly. Rather than looking like a "bum", however, he is, in fact, rather neat and well-dressed, and rather than cry out against the world in general, his concern is that he doesn't understand the world. At one point he even says, in a lower tone, before disappearing himself: "Le temps n'existe pas" (Pontalis, 1996: 137). Ironically, it is at the moment the narrator is about to shut his notebook for good that the last mysterious stranger comes by to awaken his pen once again: "Fin, commencement," he muses, "ce sont là des marques que le temps ignore, que je veux, que j'aimerais recuser [...]Autant de visages et de corps, autant d'ombres, autant de fantômes” (Pontalis, 1996: 134). If, as Augé remarks, "our practical life, our everyday life, individual and collective, both private and public, is concerned with these forms of oblivion" and "our relationship with time passes essentially through oblivion" (Augé, 2004: 25), Pontalis, through the multitude of narratives within the Café de l'Oubli's "strangers" masterly brings to light the ways in which our private ghosts can erupt among the very public ghosts of everyday interactions. 


\section{Darrieussecq’s “Flying Dutchman” (Vaisseau Fantôme)}

Marie Darrieussecq's enigmatic novel Naissance des fantômes begins directly with a husband's performing a most routine quotidian activity, going out to get the evening baguette, only to never return: "Mon mari a disparu. Il est rentré du travail, et a posé sa serviette contre le mur, il m'a demandé si j’avais acheté du pain” (Darrieussecq, 1998: 11). "Mon mari a-t-il disparu," his wife speculates, "parce que, ce soir- là, après des années de négligence de ma part, excédé, fatigué par sa journée de travail, il en a eu subitement assez de devoir, jour après jour, redescendre nos cinq étages en quête de pain? J'ai essayé d'aider les enquêteurs: était-ce vraiment un jour comme les autres?" (Darrieussecq, 1998: 11). The novel's opening scene resembles the famous "Flitcraft" episode in Dashiell Hammett's The Maltese Falcon, in which a perfectly conventional real-estate agent never returns from a business luncheon, leaving his wife and children all alone to be taken care of by an insurance claim. Later we find out that Flitcraft had, in fact, resurfaced in another state. Suddenly conscious of the randomness of daily life when a beam nearly falls on his head, he decided to create a new one in order to experience life to its fullest yet ultimately re-creates the same life he left behind. Nothing in either Flitcraft's or the narrator's husband in Naissance des fantômes would lead one to believe that they would disappear...or need to disappear. All appears to be "in order." Before calling the police, she calls her best friend (to see if by chance he might be there), but she is so enveloped in her family life (fixing the dinner, preparing the kids' baths) that she seems to offer a feeling of security to the narrator in need of a stabilized voice: "La solidité de Jacqueline dans le commencement de mon angoisse, le volume qu'elle occupait, sa découpe dans l'espace comme une hirondelle énergétique. Dans le monde qu'habitait Jacqueline, on ne pouvait pas disparaître comme ça, allant chercher le pain” (Darrieussecq, 1998: 18). Absorbed by her family duties, her friend has, in fact, no time for her: "Je suis occupée, m’a-t-elle dit, rappelle-moi plus tard" and thwarted by her impenetrability, she feels her floating away as the narrator drifts towards her lonely emotional abyss: "rassérénée sans doute par la virulente présence de mon amie (qui n'avait que faire des fils téléphoniques ou des transmissions satellites, rien ne pouvait désintégrer Jacqueline) mais esseulée aussi au bord d'une très grande mer, et je voyais s'éloigner Jacqueline qui secouait distraitement la main” (Darrieussecq, 1998 : 18).

Faced with the sudden and utterly baffling loss in her life, she, at first, mechanically tries to retrace the steps of her husband's quotidian. She painstakingly follows all of his steps in their neighborhood, and especially every boulangerie, but in the end, the last one she finds is horrifyingly "vide et noire" (Darrieussecq, 1998: 26) and the streets deserted. The now empty streets echo her newly deserted life (even though she has a son with whom she has not discussed the disappearance). Progressively and physically, this emptiness invades her entire body as she worries about "le vide dans ma poitrine" (Darrieussecq, 1998: 26) and then, like the ways of the sea, the emptiness oscillates within her: "La pesanteur bizarre de ce vide s'annulait, et puis, il revenait, il se remettait en place" (Darrieussecq, 1998: 26). As 
she comes to terms with the reality of her husband's absence, she takes refuge in the most mechanical of quotidian activities, such as brushing her teeth, but avoids looking at his toothbrush, which, surprisingly, during a party game she was unable to fully picture:

Lors d'un jeu de société, j'avais été incapable de citer sa couleur, j'en avais eu honte comme d'une inattention à l'égard de mon mari; et dans notre gêne mutuelle, nous avions cru donner là, à nos amis, une preuve de la mauvaise qualité de notre amour, comme si nous étions pris dans un piège inspiré des méthodes policières pour déjouer les mariages blancs (Darrieussecq, 1998: 32).

If Darrieussecq's narrator has trouble remembering such seemingly innocuous details as the color of her husband's toothbrush, she, of course, has trouble forgetting as well. As Augé has written, "memory and oblivion stand together, both are necessary for the full use of time [...] We would try to encourage those who intend to struggle against the hardening of the imagination [...] to not forget to forget in order to lose neither memory nor curiosity” (Augé, 2004: 89). For Augé, the notion of oblivion is, in fact, one rooted in survival: "oblivion brings us back to the present, even if it is conjugated in every tense; in the future, to live the beginning; in the present, to live in the moment; in the past to live the return [...] We must forget in order to remain present, forget in order not to die; forget in order to remain faithful” (Augé, 2004: 89). Yet, while the narrator refuses to forget her husband, remembering becomes increasingly difficult as he becomes more and more diaphanous in her unconscious, as pain replaces most of the happy memories they may have shared together. It is the presence of his absence that overwhelms her. She even tries to enter his cyberworld in order to re-connect with him, but fails in her attempts to somehow conjure him up through the machine. In the end, waiting itself becomes a type of catharsis with attempts to render concrete what is so intensely ungraspable within her:

autant d'opérations qui n'avaient sans doute de référence qu'informatique, mais qui indiquaient très réellement, sous les modifications spectrales des pixels, que peut-être, quelque part mon mari (ou quelque esprit tutélaire) continuait de penser à moi. Il m’arriva de jouer, sur divers sites, dans des espaces virtuels déjà parcourus par lui puisque son nom y était recensé; et c'était dans les intervalles, dans les moments du temps où sa concaténation ne s'effectuait plus que j'avais commençé à écrire le récit de mon attente (Darrieussecq, 1998: 114).

Even looking at a photo album of her wedding pictures becomes an alarmingly vacant activity, as she feels that she cannot even hang onto him through a medium designed to freeze time, and to hold on to memories. Parallel to her present, her husband seems invisible, while she, conversely, seems to be at the center of each photograph: "Mon mari, dont le visage n'était plus visible nulle part, se dirigeait soit vers le fond, soit vers les côtés de l'image, et le regard des gens me fixait" (Darrieussecq, 1998: 51); yet, as in many Bonnard paintings in which his lost love is represented with spectral discretion as a fade-out in a corner of the frame, she feels she is already witnessing his proto-disappearance: "Je tournais les pages de plus en plus vite, je voulais précéder la disparition de mon mari [...] j’attrapais au 
vol la silhouette d'un passant, une enjambée hors de la page, une amplitude [...] Je percevais un glissement, quelque chose qui se déchirait, un souffle sous des livres ou des cils" (Darrieussecq, 1998: 52-53). Slowly, she realizes that what she once considered the high point of her life as a married woman might have been, in fact, a foreshadowing of a life of loneliness and solitude, or rather, of a ghostly marriage before it even had time to begin: "La pelle à gâteau à la main, sur cette photo idiote qui déjà, au moment du déclic, me gênait par avance, l'absence de mon mari à mes côtés me désigne plus que jamais comme un corps étranger” (Darrieusssecq, 1998: 52). Since she fears that her husband's disappearance puts into question her own identity, the identity of her marriage is also uncertain and fragile in her eyes:

En tournant les dernières pages, où plus personne ne me jette du riz, où les regards se font indistincts, où mêmes les convives ont l'air de se demander ce qu'ils font là, me venait un soupçon horrible: mon mari, de là où il était au moment où j'assistais à sa disparition, mon mari se considérait-il désormais comme divorcé, jamais marié, libre de toute attache? Mon mari considérait-il de là où il se cachait que sa femme n'avait jamais existé? Je me suis mise à pleurer sur l’album, un herbier de moments fânés (Darrieussecq, 1998 : 52-3).

Shirley Jordan has noted that, while Darrieussecq's novels begin as though they were detective stories, they, in fact, dissipate to such a point that they are no longer about the missing individual but about the narrator's confusion and anxiety. As she observes:

Detective fiction is about finding people and finding things out about people, and it usually does just that. In Naissance des fantômes, however, the author's technique of adapting then abandoning some of its generic traits is mimetic of the heroine's progressive loss of bearings. Although she initially pursues her husband through conventional routes [...] the "script" soon fritters away. The investigation is abandoned after a few pages to be replaced by inaction and the void in the text yields no answers concerning the husband's departure (Jordan, 2002 : 148-149).

Just as the husband becomes a shadow, she begins losing weight to the point where her physical identity starts to vaporize as well: "Mes muscles se tendaient, mon ventre mollissait. Mes nerfs subissaient une traction interne. C’était le vide qui me vidait de l'intérieur, comme un pauvre poulet” (Darrieussecq, 1998 : 86). What Darrieussecq seems to be describing is, in fact, less a detective novel than an existential horror film at times in the sense that the references to vampires and vampirism are overdetermined to such an extent that they almost become obsessive. At one point, she complains of being sucked in by vampire-like forces: "Ma poitrine s'est glacée sous la vampirique succion de quelque chose d'épuisant" (Darrieussecq, 1998: 71); at another, when she wakes up, she checks to see if there are any vampire marks on her neck: "Il y a des aubes où l'on vérifie que l'on ne garde pas au cou la trace du vampire, les deux points rouges, et la pupille contractée encore de haine, les muscles endoloris par le combat” (Darrieussecq, 1998: 90). At other times, she perceives the streets as being haunted by a wave of vampires: "A chaque angle de rue battait la cape d'un vampire, les ombres épouvantées se glissaient sous les porches, se coulaient de plus en plus minces et noires dans les murs, et il me semblait entendre, par toute la ville, des froissements, des envolées 
de linge, des glissements aux marches des églises” (Darrieussecq, 1998 : 91). She describes a "vampiric energy" within her, as well as an external one, that inject her with her husband's absence, rather than presence, as though it were some sort of diabolical serum:

Au lieu de mettre à plat mon expérience, l'écrire me la renvoyait comme une balle en pleine face, chargée exactement de l'énergie vampirique (une anti-énergie comme une antimatière de trou noir qu'avait injectée dans mes veines l'absence de mon mari. Dans ce décalage, dans ce rebond, se déployait un filet dont l'emprise était d'abord aussi brutale qu'un harponnage (Darrieussecq, 1998 :115).

She becomes engulfed in the darkness of a vampire-filled night that contrasts with the "metro-boulot-dodo" diurnal world she once belonged to via her husband: "J'étais bêtement fourrée dans la gueule du loup en croyant dur comme fer que dans ma chambre aussi le jour serait levé” (Darrieussecq, 1998: 94). Her city is the antithesis of the famous film by Walter Ruttmann, Berlin Symphony of a Great City, which starts with the gates of the subway opening up optimistically before another day of work is about to begin. She imagines her mother-in-law also becoming a vampire as she searches for her son at nighttime before "dissolving" at dawn:

dissoudre dans les philtres de l'angoisse, du petit matin solitaire de ces quatre heures grises où les vampires griffent les murs et tardent à admettre l'aube, et où se lève avec le soleil quelque chose qui tape du pied, éteint les lampadaires, actionne les métro, secoue les boulangères, ouvre l'oeil des mouettes, déroule les stores (Darrieussecq, 1998 : 92).

Within the construct of the vampire narrative, it is only natural that she too must evaporate at daybreak like Max Scheck in Murnau's classic film, Nosferatu. That she should vanish too along with her husband is the logical consequence of her existential struggles as she merges with the incoming fog that sweeps across her neighborhood. She is reduced to her atomic essence. As she observes the sun in minute detail, her attention soon focuses on herself: "C'était moi, alors, qui tout entière me décomprimais en me lançant à d'autres brouillards. Le soleil faisait s'évaporer le monde, et je flottais. La ville évoluait selon les lois d'une chimie sublime, où la matière passait du solide au gazeux, esquivant l'état liquide pour se débiter peu à peu en dépense de brume" (Darrieussecq, 1998 : 103). If the title of the book refers to the birth of phantoms, the narrative succumbs to the assault of ghosts that makes the narrator lose all retinal control: "Je reconnaissais aussi la marque laissée dans l'oeil par l'assaut des fantômes, cette inaptitude à fixer le regard (par crainte ou par désir de les voir partout revenir, à la façon des phosphènes qui, la nuit, la lampe à pleine éteinte, dansent encore sur la cornée" (Darrieussecq, 1998 : 120). As Augé has predicted regarding "necessary oblivion," she yearns for a type of amnesia to take her away from her relentless panic attacks: "Il fallait être patiente, et attendre, comme dans l'impuissance de l'amnésie, que sous l'effet du repos, la brume se déchire, qu'au vu d'un petit rien, un souvenir surgisse, qu'à un carrefour, un croisement, quelque chose revienne” (Darrieussecq, 1998 : 121). 
In the end, she is unable to visualize her husband naked anymore, or even to remember what kind of clothing he used to wear. Yet, although the very first line of the novel ended with the verb "disparaître," the last line, perhaps optimistically, on the verge of a healing impulse, ends with the verbs "sentir" and "voir": "Je sais seulement avoir cessé, à ce moment-là, de me demander si mon mari (si les chats, les oiseaux, les poissons, et les mouches aux yeux à facettes) se sentait et voyait tout de même ce que moi je sentais et voyais” (Darrieussecq, 1998: 162). No longer dangerously isolated and victimized, she becomes defiantly individualized, one among many living, feeling, seeing creatures. It is as though her husband's dreadful disappearance forced her out of a mechanical and safe routine. As a result of this, she is forced to investigate, if not re-appropriate the space around her. As Kathryn Robson suggests, it is through a Freudian process of mourning and melancholy that Darrieussecq's characters can repiece their proper identities (rather than living through an another): "Instead of taking death as the defining example and model for all loss, we could gain insight from those examples of the disappearance of the other. Here, mourning is not so much about accepting the loss of the other as about recreating one's own identity so that it is no longer rooted in the bodily presence of the other" (Robson, 2004: 14). Indeed, if there are so many references to vampires in the novel, it could also be because her husband simply vanished without leaving a body to mourn and to bury or to put a tomb over. Rather, it is the emptiness around her that forces her to create and, eventually, re-invent a new life within her: "Le vide autour de moi prenait comme une dalle, un ciment qui se solidifiait et devenait palpable, une certaine qualité de l'air, de l'ombre, du silence, une certaine immobilité des murs, une certaine verticalité des portes et des fenêtres" (Darrieussecq, 1998: 85). Magritte may well have declared "Ceci n'est pas une pipe" regarding the representation of a pipe on his canvas, Darrieussecq's narrator must assert: “Ceci n'est pas une dalle” and live to tell the tale.

Ultimately, the theme of disappearance in much French fiction in the later part of the 1990s points to a certain fascination among authors with what was missing or hidden within society rather than with the much talked about threats (such as the Y2K computer scare) that had been so overblown in the media. The present, it would seem, would not be as attractive as the past which, surprisingly in an ostensibly unsentimental and detached era, could be viewed with a sense of mourning and melancholy. Attachment to what may not be seen, but what is deeply felt, discretely held among the recesses of the collective or personal unconscious, is a type of "clinamen", so to speak, that has sparked an elliptical wave of art and literature (as Stephen Greenblatt discusses, for example, in his recent book The Swerve: How the World Became Modern). If George Perec's famous quotation from Jules Verne's Michel Strogoff, "Regarde, regarde avec tous tes yeux”, could be used at the beginning of a book meant to reveal the fleeting artistry of the inhabitants hidden behind the walls of an apartment building which will soon be taken down in La Vie mode d'emploi, it can also apply to the end of a century as well. "Un jour surtout, c'est la maison entière qui disparaîtra”, Perec warns through one of his 
characters, "c'est la rue et le quartier entiers qui mourront” (Perec, 1978: 109). Indeed, the narratives of disappearance that pepper our last fin de siècle seem to urge the modern reader to look hard at our own space lest the invisible be washed away with as much speed as the flickering images that spew from our television sets, flashing billboards and computer screens.

\section{WORKS CITED}

Abbas, A., (1997) Hong Kong: Culture and the Politics of Disappearance. Minneapolis, University of Minnesota Press.

Augé, M., (1992) Non-lieux: Introduction à une anthropologie de la modernité. Paris, Editions du Seuil.

Augé, M., (2004) Oblivion. Forward by J. E. Young. Trans. M. de Jager. Minneapolis, University of Minnesota Press.

Calle, S., (2003) M'as-tu vue? Arles, Actes du Sud.

Certeau, M. de., (1990) L'invention du quotidien. Vol 1. Arts de faire. Paris, Union Générale de l’Edition.

Darrieussecq, M., (1998) Naissance des fantômes. Paris, P.O.L.

Darrieussecq, M., (2001) Bref séjour chez les vivants. Paris, P.O.L.

Darrieussecq, M., (2006, November 1) "Je suis devenue psychanalyste” avec Bapiste Ligier in l'Express [En ligne]. Available at: www.lexpress.fr/culture/livre [Latest access June 3, 2015].

Darrieussecq, M., (2007) Tom est mort. Paris, P.O.L.

Greenblatt, S., (2012) The Swerve: How the World Became Modern. New York, W.W. Norton and Co.

Hammett, D., (1930) The Maltese Falcon. New York, London, Alfred A. Knopf. Jordan, S., (2002) "Saying the Unsayable: Identities in Crisis in the Early Novels of Marie Darrieussecq” in Rye, G \& M. Worton (ed), Women's Writing in Contemporary France: New Writers, New Literatures in the 1990's. Manchester, Manchester University Press, pp. 143-153.

Lipovetsky, G., (1983) L'ère du vide: Essais sur l'individualisme contemporain. Paris, Gallimard.

Mango, E. G., (2014) “J.-B. Pontalis, a Thinker of psychoanalysis” in The International Journal of Psychoanalysis. Vol. 95, pp. 525-532.

Modiano, P., (1968) La Place de l'étoile. Paris: Gallimard.

Modiano, P., (1993) Chien de printemps. Paris, Seuil.

Modiano, P., (1997) Dora Bruder. Paris, Gallimard, "Collection Blanche”.

Nosferatu, (1922) [Film] Directed by Murnau, F. W. Germany, Prana-Film.

Perec, G., (1978) La vie mode d'emploi. Paris, Hachette.

Pontalis, J. B., (1996) Un homme disparaît. Paris, Gallimard.

Pontalis, J. B., (1997) Ce temps qui ne passe pas. Paris, Gallimard.

Queneau, R., (1933) Le chiendent. Paris, Gallimard.

Queneau, R., (1959) Zazie dans le metro. Paris, Gallimard. 
Robson, K., (2004) “The Subject of Loss in Marie Darrieussecq's Naissance des fantômes and Régine Detambel's La chambre d'écho" in Australian Journal of French Studies. Vol 41, n 1, Jan-March., pp. 3-15.

Berlin: Symphony of a Great City, (1927) [Film] Directed by Ruttmann, W. Germany, Deutsche Vereins-Film/ Les Productions Fox-Europe.

Mon oncle, (1958) [Film] Directed by Tati, J. France, Cardy Films/Discina.

Virilio, P., (1989) Esthétique de la disparition. Paris, Galilée.

Virilio, P., (1990) L'inertie polaire. Paris, Christian Bourgeois.

Virilio, P., (1996) Cybermonde: La politique du pire. Entretiens avec Philippe Petit. Paris, Textuel.

Virilio, P., (1999) Politics of the Very Worst: An interview with Philippe Petit. Trans. S. Lotringer. New York, Semiotexte.

Virilio, P., (2008) Bunker archéologie. Paris, Galilée. 